\title{
ANALISIS CLUSTER NON-HIRARKI DENGAN METODE $K$-MODES
}

\author{
Indah Ayuningtias, Naomi Nessyana Debataraja, Nurfitri Imro'ah
}

\begin{abstract}
INTISARI
Analisis cluster merupakan suatu analisis multivariat yang digunakan untuk mengelompokkan objek-objek berdasarkan kemiripan karakteristik yang dimiliki. Salah satu teknik dari analisis cluster adalah metode KModes. Tujuan dari penelitian ini adalah untuk mengetahui jumlah cluster terbaik yang digunakan dalam pemilihan kegiatan ekstrakurikuler menari. Perbandingan hasil validitas cluster dilakukan berdasarkan nilai Davies-Bouldin Index (DBI) terkecil yang dihasilkan pada masing-masing cluster yaitu 2 cluster dan 3 cluster. Berdasarkan hasil analisis yang telah dilakukan pada perbandingan nilai DBI, diperoleh nilai terkecil sebesar 0,52 pada 2 cluster. Hasil penelitian menunjukkan bahwa cluster terbaik yang dihasilkan pada pemilihan kegiatan ekstrakurikuler menari adalah dengan menggunakan 2 cluster dimana anggota cluster 1 terdiri dari 56 siswi dan anggota cluster 2 terdiri dari 36 siswi.
\end{abstract}

Kata Kunci: analisis multivariat, $k$-modes, davies-bouldin index.

\section{PENDAHULUAN}

Analisis multivariat merupakan metode statistika yang digunakan untuk menganalisis data yang terdiri dari banyak variabel serta pendugaan antar variabel saling berhubungan satu sama lain[1]. Analisis multivariat dapat digunakan untuk mengatasi permasalahan seperti pengelompokkan objekobjek yang mempunyai persamaan karakteristik. Analisis yang dapat digunakan dalam mengatasi permasalahan tersebut yaitu Analisis Cluster. Analisis Cluster bertujuan untuk mengelompokkan objek-objek berdasarkan kemiripan karakteristik yang dimiliki[2]. Kemudian objek tersebut dipisah ke dalam satu atau lebih kelompok sehingga objek-objek tersebut berada dalam satu cluster. Terdapat dua metode dalam analisis cluster yaitu analisis cluster hirarki dan analisis cluster nonhirarki.

Perbedaan antara analisis cluster hirarki dan analisis cluster non-hirarki terletak pada awal untuk memulai pengelompokkan. Pada analisis cluster hirarki dimulai dengan dikelompokkannya dua atau lebih objek yang kesamannya paling dekat sehingga cluster akan membentuk seperti pohon yang terdapat tingkatan jelas antar objek, seperti dari objek yang mempunyai kesamaan dekat hingga yang paling tidak dekat. Berbeda dengan metode hirarki, analisis cluster non-hirarki dimulai dengan terlebih dahulu menentukan jumlah cluster yang diinginkan peneliti (dua, tiga, atau lebih). Setelah menentukan cluster, menempatkan objek-objek ke dalam cluster dan tidak mengikuti proses hirarki. Dalam analisis cluster non-hirarki terdapat metode yang sering digunakan, yaitu metode $K$-Means. Akan tetapi permasalahan yang terjadi pada metode ini hanya terbatas pada penggunaan data dengan tipe numerik (interval/rasio). Permasalahan tersebut dapat diatasi dengan menerapkan metode $K$-Modes yang merupakan modifikasi dari metode $K$-Means[3].

$K$-Modes merupakan suatu metode pada analisis cluster non-hirarki yang dapat berjalan dengan baik untuk sekelompok data yang berbentuk kategorikal (nominal atau ordinal). Metode ini menggunakan ukuran pencocokan ketidakmiripan sederhana pada data kategorikal, seperti modus (nilai yang paling sering muncul) untuk menentukan cluster sebagai centroid (pusat) dan menggunakan metode seperti frekuensi untuk mencari modus dari nilai-nilai yang didapat [4]. Pada metode ini, penentuan jumlah cluster dilakukan di awal sebelum analisis dilakukan. Penulis menentukan cluster yang dibentuk yaitu 2 cluster dan 3 cluster yang digunakan untuk mengetahui jumlah cluster yang cocok digunakan untuk mengelompokkan siswi-siswi dalam memilih kegiatan ekstrakurikuler menari. 
Tujuan yang dicapai dari penelitian ini adalah menentukan validitas dari cluster yang dihasilkan, menentukan variabel yang menjadi pusat cluster paling optimal dan menentukan hasil dari pengelompokkan anggota yang terjadi pada cluster terbaik yang dihasilkan. Penelitian ini menggunakan data primer berupa kuesioner tentang pertimbangan pemilihan menari sebagai kegiatan ekstrakurikuler. Dalam kuesioner data berbentuk nominal, sehingga metode yang digunakan adalah analisis cluster non-hirarki dengan metode $K$-Modes.

Penelitian ini berupa studi literatur dan studi kasus yang dimulai pemberian kuesioner kepada responden. Selanjutnya, dilakukan uji validitas dan uji reliabilitas terhadap data. Langkah selanjutnya adalah menentukan jumlah cluster, yaitu 2 cluster dan 3 cluster. Kemudian menentukan centroid dengan memilih 2 data sebagai modus awal didapat dengan mengambil sampel secara acak, menghitung jarak atau ketidakmiripan data setiap centroid, menghitung pusat cluster baru, menghitung nilai fungsi objektif untuk mengetahui batas optimal cluster. Setelah itu, melakukan pengujian validitas cluster yang dihasilkan dengan membandingkan nilai DBI pada masing-masing cluster yang terbentuk.

\section{UJI VALIDITAS}

Uji validitas bertujuan untuk mengukur mengukur ketepatan instrumen yang digunakan dalam suatu penelitian. Untuk mencari validitas digunakan dengan uji hipotesis dan kriteria uji sebagai berikut:

$H_{0}$ : butir pertanyaan tidak valid.

$H_{1}$ : butir pertanyaan valid.

Statistik uji yang digunakan adalah[4]:

$$
r_{\text {hitung }}=\frac{n \sum_{i=1}^{n} x_{i} y_{i}-\left(\sum_{i=1}^{n} x_{i}\right)\left(\sum_{i=1}^{n} y_{i}\right)}{\left(\sqrt{n \sum_{i=1}^{n} x_{i}^{2}-\left(\sum_{i=1}^{n} x_{i}\right)^{2}}\right)\left(\sqrt{n \sum_{i=1}^{n} y_{i}^{2}-\left(\sum_{i=1}^{n} y_{i}\right)^{2}}\right)}
$$

dimana $r_{\text {hitung }}$ adalah korelasi antara variabel independen dengan $x_{i}$ adalah skor item butir soal ke$i, y_{i}$ adalah skor total butir soal ke- $i$, dan $n$ adalah jumlah sampel.

Kriteria pengambilan keputusan yakni tolak $H_{0}$ jika nilai $r_{\text {hitung }}>r_{a, d b_{(n-2)}}$. Jika $H_{0}$ diterima maka mengeluarkan butir pertanyaan yang tidak valid.

\section{UJI RELIABILITAS}

Uji reliabilitas digunakan untuk menguji konsistensi suatu instrumen yang digunakan dalam penelitian dengan tahapan sebagai berikut:

$H_{0}$ : butir pertanyaan tidak reliabel.

$H_{1}$ : butir pertanyaan reliabel.

Statistik uji yang digunakan adalah[5]:

$$
r_{\text {Cronbach'sAlpha }}=\left(\frac{r}{r-1}\right)\left(1-\frac{\sum_{i=1}^{r} s_{i}^{2}}{s_{t}^{2}}\right)
$$

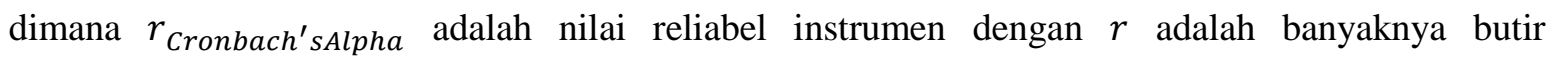
pertanyaan, $s_{i}^{2}$ adalah variansi skor butir dan $s_{t}^{2}$ adalah variansi skor total.

dengan[8]:

$$
\begin{aligned}
s_{i}{ }^{2} & =\frac{\sum_{j=1}^{n} a_{j}{ }^{2}}{n}-\left[\frac{\sum_{j=1}^{n} a_{j}}{n}\right]^{2} \\
s_{t}{ }^{2} & =\frac{\sum_{j=1}^{n} y_{j}{ }^{2}}{n}-\left[\frac{\sum_{j=1}^{n} y_{j}}{n}\right]^{2}
\end{aligned}
$$

dimana $a_{j}$ adalah data ke-j, $n$ adalah jumlah keseluruhan data dan $y_{j}$ adalah skor total. 
Kriteria pengambilan keputusan yakni tolak $H_{0}$ jika nilai $r_{\text {hitung }}>0,60$. Jika $H_{0}$ diterima maka butir pertanyaan tidak reliabel. Sehingga kuesioner disebar ulang setelah dikaji oleh peneliti.

\section{K-MODES CLUSTER}

Metode K-Modes dapat digunakan untuk tipe data kategorikal (nominal dan ordinal). Ukuran ketidakmiripan antara dua data diukur dengan jumlah ketidakcocokan nilai dari fitur yang berkorespondensi. Semakin kecil nilai ketidakcocokan, maka semakin mirip dua data tersebut. Pengukuran seperti ini disebut dengan pencocokan sederhana dengan rumus sebagai berikut[6]:

$$
d(A, B)=\sum_{i=1}^{n} \sum_{j=1}^{n} \sum_{q=1}^{r} \in\left(a_{i q}, b_{j q}\right)
$$

dengan syarat:

$$
\in\left(a_{i q}, b_{j q}\right)=\left\{\begin{array}{l}
0\left(a_{i q}=b_{j q}\right) \\
1\left(a_{i q} \neq b_{j q}\right)
\end{array}\right.
$$

dimana $\in\left(a_{i q}, b_{j q}\right)$ adalah nilai pencocokan, $n$ adalah banyaknya data, $r$ adalah banyaknya variabel, $a_{i q}$ adalah data ke- $i$ variabel ke- $q$ dan $b_{j q}$ adalah centroid data ke- $i$ variabel ke- $q$.

Sebelum mencari nilai fungsi objektif, terlebih dahulu menghitung nilai ketidakmiripan data dengan modus baru dari tiap-tiap cluster dengan persamaan sebagai berikut[6]:

$$
d(A, P)=\sum_{i=1}^{n} d\left(a_{i q}, p_{l q}\right)
$$

dimana $p_{l q}$ adalah modus ke- $l$ variabel ke- $q$.

Untuk mencari nilai fungsi objektif, persamaan yang digunakan adalah sebagai berikut[6]:

$$
J(t)=\sum_{l=1}^{k} \sum_{i=1}^{n} \sum_{q=1}^{r} w_{i, r} \in\left(a_{i q,} p_{l q}\right)
$$

dimana $\in\left(a_{i q}, p_{l q}\right)$ adalah nilai pencocokan data dengan modus dan $w_{i, r}$ adalah nilai keanggotaan data pada setiap cluster dan memiliki nilai [0,1]. Bernilai 1 jika data sesuai pada cluster 1 atau cluster 2. Bernilai 0 jika data tidak sesuai pada clusternya.

\section{VALIDITAS CLUSTER DAVIES-BOULDIN INDEX}

Pengukuran Davies-Bouldin Index (DBI) digunakan untuk mengevaluasi cluster. Validasi internal yang dilakukannya adalah seberapa baik clustering sudah dilakukan dengan menghitung kuantitas dan fitur turunan dari himpunan data. Sum of square within cluster (SSW) sebagai pengukuran kohesi dalam sebuah cluster ke-i dapat menggunakan perhitungan oleh persamaan sebagai berikut[6]:

$$
S S W_{i}=\frac{1}{m_{i}} \sum_{j=1}^{m_{i}} d\left(a_{i}, c_{j}\right)
$$

dimana $S S W_{i}$ adalah ukuran kohesi atau ukuran keserasian dalam cluster ke-i, $m_{i}$ adalah data yang berada dalam cluster ke- $i$ dan $c_{j}$ adalah modus akhir data ke- $j$

Pengukuran untuk separasi atau ukuran keterpisahan antara dua cluster, misalkan cluster $i$ dan $j$ digunakan perhitungan Sum of square between cluster (SSB) dengan mengukur jarak centroid $c_{i}$ dan $c_{j}$ seperti pada persamaan berikut[6]:

$$
S S B_{i, j}=d\left(c_{i}, c_{j}\right)
$$

dimana $S S B_{i, j}$ adalah ukuran separasi antara cluster ke-i dan cluster ke-j.

Cluster yang baik adalah cluster yang mempunyai kohesi yang sekecil mungkin dan reparasi yang sebesar mungkin. $R_{i, j}$ dapat dihitungan dengan persamaan berikut[6]:

$$
R_{i, j}=\frac{S S W_{i}+S S W_{j}}{S S B_{i, j}}
$$

dimana $R_{i, j}$ adalah ukuran rasio seberapa baik perbandingan antara cluster ke- $i$ dan cluster ke-j.

Nilai Davies-Bouldin Index (DBI) didapatkan dari persamaan berikut[6]: 


$$
D B I=\frac{1}{K} \sum_{i=1}^{2} \sum_{=1}^{K} \max _{i \neq j}\left(R_{i, j}\right)
$$

dimana $k$ adalah jumlah cluster yang digunakan.

\section{HASIL DAN PEMBAHASAN}

Data pada penelitian ini menggunakan data primer berupa kuesioner tentang pertimbangan pemilihan menari sebagai kegiatan ekstrakurikuler. Penelitian ini menggunakan 5 variabel, yaitu pilihan kegiatan menari, ajakan menari, banyaknya ikut lomba, rutinitas latihan tiap 1 minggu dan lama latihan. Tabel 1 menyajikan hasil analisis dekriptif untuk setiap variabel.

Tabel 1 Analisis Deskriptif

\begin{tabular}{|c|c|c|c|c|}
\hline No. & Variabel & Jawaban & Frekuensi & Persentase \\
\hline \multirow{4}{*}{1.} & \multirow{4}{*}{ Pilihan Ekskul } & Pertama & 40 & $43,48 \%$ \\
\hline & & Kedua & 38 & $41,30 \%$ \\
\hline & & Ketiga & 14 & $15,22 \%$ \\
\hline & & Keempat & 0 & $0 \%$ \\
\hline \multirow{4}{*}{2.} & \multirow{4}{*}{ Inisiatif Ekskul } & Sendiri & 40 & $43,48 \%$ \\
\hline & & Orang tua & 44 & $47,83 \%$ \\
\hline & & Teman & 8 & $8,69 \%$ \\
\hline & & Guru & 0 & $0 \%$ \\
\hline \multirow{4}{*}{3.} & \multirow{4}{*}{ Mengikuti Lomba } & Tidak Pernah & 19 & $20,65 \%$ \\
\hline & & 1-3 kali & 33 & $35,87 \%$ \\
\hline & & 4-5 kali & 24 & $26,09 \%$ \\
\hline & & $>5$ kali & 16 & $17,39 \%$ \\
\hline \multirow{4}{*}{4.} & \multirow{4}{*}{ Rutinitas } & 1 kali seminggu & 31 & $33,70 \%$ \\
\hline & & 2 kali seminggu & 43 & $46,74 \%$ \\
\hline & & 3 kali seminggu & 15 & $16,30 \%$ \\
\hline & & 4 kali seminggu & 3 & $3,26 \%$ \\
\hline \multirow{4}{*}{5.} & \multirow{4}{*}{ Lama Latihan } & 30-60 menit & 9 & $9,78 \%$ \\
\hline & & 60-90 menit & 26 & $28,26 \%$ \\
\hline & & 90-120 menit & 41 & $44,56 \%$ \\
\hline & & $>120$ menit & 16 & $17,40 \%$ \\
\hline
\end{tabular}

Pada Tabel 1 menjelaskan secara rinci frekuensi dan persentase tiap variabel yang dipilih oleh responden. Tahap awal pengerjaan penelitian ini, dilakukan uji validitas dan reliabilitas terhadap butir pertanyaan. Kuesioner disebarkan kepada 30 responden dengan pembagian 15 responden siswi Sekolah Menengah Pertama (SMP) dan 15 siswi Sekolah Menengah Atas (SMA) di Sanggar Bougenville.

Tabel 2 Uji Validitas

\begin{tabular}{cccc}
\hline Butir Pertanyaan & $r_{\text {hitung }}$ & $r_{\text {tabel }}$ & Keterangan \\
\hline 1 & 0,836 & 0,374 & Valid \\
2 & 0,528 & 0,374 & Valid \\
3 & 0,482 & 0,374 & Valid \\
4 & 0,856 & 0,374 & Valid \\
5 & 0,710 & 0,374 & Valid \\
\hline
\end{tabular}

Berdasarkan Tabel, 2 nilai $r_{\text {hitung }}>r_{a, d b_{(n-2)}}$, maka $H_{0}$ ditolak, sehingga dapat disimpulkan bahwa semua butir pertanyaan keputusan siswi valid.

Uji reliabilitas digunakan untuk menguji konsistensi suatu instrumen yang digunakan dalam penelitian. Berdasarkan perhitungan, diperoleh nilai $r_{\text {Cronbach's Alpha }}$ yaitu 0,705 > 0,60 maka 
didapat hasil $H_{0}$ ditolak. Sehingga dapat disimpulkan bahwa semua butir pertanyaan keputusan siswa reliabel.

Setelah dinyatakan valid dan reliabel, dilakukan penentuan sampel untuk mencari jumlah responden yang dibutuhkan[7].

$$
n=\frac{N}{1+N e^{2}}
$$

dimana $n$ adalah jumlah sampel sebanyak 92 siswi , $N$ adalah jumlah populasi sebanyak 120 siswi dan $e$ adalah batas toleransi dengan nilai 0,05 .

\section{ANALISIS K-MODES 2 CLUSTER}

Dipilih 2 data sebagai modus awal secara acak. Data dipilih sesuai dengan modus pada masingmasing variabel. Karena tidak ada data yang sama dengan modus, maka dipilih data yang hampir sama. Dipilih data ke-7 sebagai centroid 1, dan data ke-14 sebagai centroid 2. Pada pembahasan ini $a_{i}$ merupakan nilai dari setiap jawaban responden dan $c_{i}$ merupakan modes awal yang telah dipilih secara acak.

Tabel 4 Centroid Awal Iterasi Pertama 2 Cluster

\begin{tabular}{cccccc}
\hline Centroid & Pilihan & Ajakan & Lomba & Rutinitas & Lama Latihan \\
\hline 1 & 1 & 2 & 2 & 1 & 3 \\
2 & 1 & 1 & 3 & 2 & 3 \\
\hline
\end{tabular}

Dilakukan iterasi pertama yaitu menghitung ketidakmiripan setiap data ke centroid (modus) awal. Berikut adalah perhitungan jarak ke setiap centroid:

1. Data ke-1

$$
\begin{aligned}
d\left(a_{1 q}, b_{1 q}\right)= & \in\left(a_{11}, b_{11}\right)+\in\left(a_{12}, b_{12}\right)+\in\left(a_{13}, b_{13}\right)+\in\left(a_{14}, b_{14}\right)+\in\left(a_{15}, b_{15}\right) \\
= & \in(2,1)+\in(2,2)+\in(1,2)+\in(2,1)+\in(1,3) \\
= & 1+0+1+1+1=4 \\
d\left(a_{1 q}, b_{2 q}\right)= & \in\left(a_{11}, b_{21}\right)+\in\left(a_{12}, b_{22}\right)+\in\left(a_{13}, b_{23}\right)+\in\left(a_{14}, b_{24}\right)+\in\left(a_{15}, b_{25}\right) \\
= & \in(2,1)+\in(2,1)+\in(1,3)+\in(2,2)+\in(1,3) \\
& =1+1+1+0+1=4
\end{aligned}
$$

Perhitungan yang sama dilakukan hingga mencapai data ke 92. Perhitungan jarak data ke centroid dapat dilihat pada Tabel 5 yaitu penentuan letak cluster didasarkan pada jarak terdekat anggota data ke-i dengan centroid.

Tabel 5 Jarak Data ke Centroid Iterasi Pertama 2 Cluster

\begin{tabular}{ccccc}
\hline \multirow{2}{*}{ Data ke- } & \multicolumn{2}{l}{ Jarak ke Centroid } & Terdekat & Cluster yang Diikuti \\
\hline 1 & 1 & 2 & 4 & 1 \\
2 & 4 & 4 & 4 & 1 \\
$\vdots$ & 4 & 4 & $\vdots$ & $\vdots$ \\
91 & $\vdots$ & $\vdots$ & 2 & 1 \\
92 & 2 & 3 & 0 & 2 \\
\hline
\end{tabular}

Berdasarkan Tabel 5, data ke-1 jarak data ke centroid 1 dan centroid 2 masing-masing adalah 4. Karena nilai keduanya sama, maka jarak terdekat dari data ke centroid 1 dan data ke-1 masuk ke dalam cluster 1 . Pada data ke-92 jarak data ke centroid 1 dan centroid 2 masing-masing adalah 3 dan 0 dimana nilai 0 adalah nilai terkecil atau jarak terdekat dari data ke centroid 2, maka data ke92 masuk ke dalam cluster 2.

Modus yang telah didapatkan merupakan centroid baru dari kedua cluster yang telah didapatkan. Selanjutnya, modus pada cluster 1 merupakan centroid 1 dan modus pada cluster 2 
meruapakan centroid 2. Nilai fungsi objektif setiap data dengan centroid baru dari masing-masing cluster dapat dihitung menggunakan Persamaan (5). Tujuan dari nilai fungsi objektif adalah untuk mengetahui apakah cluster sudah mencapai batas optimal.

a. Cluster 1

$$
\begin{aligned}
d\left(a_{1 q}, p_{1 q}\right)= & \in\left(a_{11}, p_{11}\right)+\in\left(a_{12}, p_{12}\right)+\in\left(a_{13}, p_{13}\right)+\in\left(a_{14}, p_{14}\right)+\in\left(a_{15}, p_{15}\right) \\
= & \in(1,2)+\in(2,2)+\in(1,2)+\in(2,1)+\in(1,3) \\
= & 0+0+1+1+1=3 \\
d\left(a_{3 q}, p_{1 q}\right)= & \in\left(a_{31}, p_{11}\right)+\in\left(a_{32}, p_{12}\right)+\in\left(a_{33}, p_{13}\right)+\in\left(a_{34}, p_{14}\right)+\in\left(a_{35}, p_{15}\right) \\
= & \in(2,2)+\in(2,2)+\in(4,2)+\in(2,1)+\in(2,3) \\
= & 0+0+1+1+1=3
\end{aligned}
$$

Perhitungan yang sama dilakukan hingga 57 data pada cluster 1 dan 35 data pada cluster 2 . Dengan demikian diperoleh nilai fungsi objektif pada iterasi pertama adalah sebagai berikut:

$$
\begin{gathered}
J(1)=\sum_{l=1}^{2} \sum_{i=1}^{92} \sum_{j=1}^{5} w_{i, l} \in\left(a_{i, j}, p_{l, j}\right) \\
J(1)=w_{1,1} \in\left(a_{1,1}, p_{1,1}\right)+w_{1,1} \in\left(a_{1,2}, p_{1,2}\right)+\cdots+w_{2,5} \in\left(a_{92,5}, p_{2,5}\right) \\
=1(3)+1(3)+\ldots+1(0)=206
\end{gathered}
$$

Nilai fungsi objektif pada iterasi pertama yaitu 206. Untuk mengetahui apakah cluster sudah optimal, dilakukan proses clustering ke iterasi berikutnya. Perhitungan yang sama dilakukan untuk iterasi selanjutnya hingga didapatkan nilai perubahan fungsi objektif sekarang sama dengan fungsi objektif sebelumnya.

Tabel 6 Hasil K-Modes 2 Cluster

\begin{tabular}{ccc}
\hline Iterasi & $\begin{array}{c}\text { Nilai Fungsi } \\
\text { Objektif }\end{array}$ & $\begin{array}{c}\text { Perubahan Fungsi } \\
\text { Objektif }\end{array}$ \\
\hline Pertama & 206 & - \\
Kedua & 196 & 10 \\
Ketiga & 196 & 0 \\
\hline
\end{tabular}

Anggota kelompok yang masuk dalam cluster 1 sebanyak 56 data dengan kategori pilihan kegiatan ekstrakurikuler menari kedua, ajakan masuk di Sanggar Bougenville dari orang tua, pernah mewakili sekolah dalam lomba menari sebanyak 1-3 kali, rutinitas menari 1 hari dalam seminggu dan rata-rata lama latihan adalah 90-120 menit perhari. Anggota kelompok yang masuk dalam cluster 2 sebanyak 36 data dengan kategori pilihan kegiatan ekstrakurikuler menari pertama, ajakan masuk di Sanggar Bougenville dari diri sendiri, pernah mewakili sekolah dalam lomba menari sebanyak 4-5 kali, rutinitas menari 2 hari dalam seminggu dan rata-rata lama latihan adalah 90-120 menit perhari.

\section{ANALISIS K-MODES 3 CLUSTER}

Dipilih 3 data sebagai modus awal secara acak. Data dipilih sesuai dengan modus pada masingmasing variabel. Karena tidak ada data yang sama dengan modus, maka dipilih data yang hampir sama. Dipilih data ke-7 sebagai centroid 1, data ke-14 sebagai centroid 2 dan data ke-19 sebagai centroid 3. Perhitungan dan langkah-langkah pengerjaan sama dengan analisis K-Modes 2 Cluster.

Tabel 7 Hasil K-Modes 3 Cluster

\begin{tabular}{ccc}
\hline Iterasi & $\begin{array}{c}\text { Nilai Fungsi } \\
\text { Objektif }\end{array}$ & $\begin{array}{c}\text { Perubahan Fungsi } \\
\text { Objektif }\end{array}$ \\
\hline Pertama & 176 & - \\
Kedua & 165 & 11 \\
Ketiga & 160 & 5 \\
Keempat & 160 & 0 \\
\hline
\end{tabular}


Anggota kelompok yang masuk dalam cluster 1 sebanyak 41 data dengan kategori pilihan kegiatan ekstrakurikuler menari kedua, ajakan masuk di Sanggar Bougenville dari orang tua, pernah mewakili sekolah dalam lomba menari sebanyak 1-3 kali, rutinitas menari 1 hari dalam seminggu dan rata-rata lama latihan adalah 90-120 menit perhari. Anggota kelompok yang masuk dalam cluster 2 sebanyak 33 data dengan kategori pilihan kegiatan ekstrakurikuler menari pertama, ajakan masuk di Sanggar Bougenville dari diri sendiri, pernah mewakili sekolah dalam lomba menari sebanyak 4 -5 kali, rutinitas menari 2 hari dalam seminggu dan rata-rata lama latihan adalah 90-120 menit perhari. Anggota kelompok yang masuk dalam cluster 3 sebanyak 18 data dengan kategori pilihan kegiatan ekstrakurikuler menari pertama, ajakan masuk di Sanggar Bougenville dari orang tua, pernah mewakili sekolah dalam lomba menari sebanyak 1-3 kali, rutinitas menari 1 hari dalam seminggu dan rata-rata lama latihan adalah 60-90 menit perhari.

\section{VALIDITAS CLUSTER}

Untuk mengetahui cluster mana yang baik digunakan dalam penelitian ini, maka digunakan perhitungan validitas cluster dengan menggunakan Davies-Bouldin Index (DBI).

1. Nilai DBI 2-Cluster

Nilai Sum of square within cluster (SSW) pada cluster 1 didapat dengan menggunakan Persamaan (7) sebagai berikut:

$$
\begin{aligned}
S S W_{1} & =\frac{1}{m_{1}} \sum_{j=1}^{m_{1}} d\left(a_{j}, c_{1}\right) \\
& =\frac{1}{56} \sum_{j=1}^{56}(3+3+\cdots+2+3) \\
& =\frac{1}{56}(130)=2,32
\end{aligned}
$$

Nilai SSW pada cluster 1 diperoleh sebesar 2,32, yang berarti bahwa kedekatan hubungan data dengan cluster 1 sebesar 2,32.

Nilai Sum of square within cluster (SSW) pada cluster 2 didapat dengan menggunakan Persamaan (7) sebagai berikut:

$$
\begin{aligned}
S S W_{2} & =\frac{1}{36} \sum_{j=1}^{36}(2+3+\cdots+1+0) \\
& =\frac{1}{36}(66)=1,83
\end{aligned}
$$

Nilai SSW pada cluster 2 diperoleh sebesar 1,83, yang berarti bahwa kedekatan hubungan data dengan cluster 2 sebesar 1,83.

Nilai Sum of Square Between cluster (SSB) kedua cluster didapat dengan menggunakan Persamaan (8) sebagai berikut:

$$
\begin{aligned}
S S B_{1,2} & =d\left(c_{1}, c_{2}\right) \\
& =\in(2,1)+\in(2,1)+\in(2,3)+\in(1,2)+\in(3,3) \\
& =1+1+1+1+0=4
\end{aligned}
$$

Nilai SSB antara cluster 1 dan cluster 2 diperoleh sebesar 4, berarti bahwa nilai keterpisahan antar cluster berbeda.

Nilai rasio perbandingan antar cluster didapat dengan menggunakan Persamaan (9) sebagai berikut:

$$
\begin{aligned}
R_{1,2} & =\frac{S S W_{1}+S S W_{2}}{S S B_{1,2}} \\
& =\frac{2,32+1,83}{4}=1,04
\end{aligned}
$$

Nilai rasio perbandingan antara cluster 1 dan cluster 2 adalah sebesar 1,04. Berarti antara cluster 1 dan cluster 2 memiliki ukuran rasio sebesar $104 \%$. 
Nilai DBI didapat dengan menggunakan Persamaan (10) sebagai berikut:

$$
D B I=\frac{1}{2} \sum_{i=1}^{2} \sum_{j=1}^{2} \max _{i \neq j}\left(R_{1,2}\right)=\frac{1}{2}(1,04)=0,52
$$

Tabel 8 Nilai Davies-Bouldin Index (DBI)

\begin{tabular}{cc}
\hline Cluster & DBI \\
\hline 2 & 0,52 \\
3 & 1,18 \\
\hline
\end{tabular}

Berdasarkan Tabel 8, diperoleh nilai DBI pada cluster 2 dan 3 masing-masing adalalah 0,52 dan 1,18. Cluster yang baik merupakan cluster yang mempunyai nilai DBI yang terkecil. Dapat disimpulkan banyaknya cluster yang cocok pada analisis cluster non-hirarki dengan metode $K$ Modes berdasarkan pemilihan menari sebagai kegiatan ekstrakurikuler adalah dengan menggunakan 2 cluster dengan nilai DBI sebesar 0,52.

\section{KESIMPULAN}

Berdasarkan hasil perhitungan dan pembahasan dapat disimpulkan bahwa cluster paling optimal dengan menggunakan $K$-Modes 2 cluster. Nilai validitas Davies-Bouldin Index (DBI) yang dihasilkan sebesar 0,52. Anggota kelompok yang masuk dalam cluster 1 sebanyak 56 data dan cluster 2 sebanyak 36 data. Pada cluster 1 kegiatan ekstrakurikuler menari masih menjadi pilihan kedua dan ajakan dari orang tua. Dengan rutinitas menari yaitu 1 kali dalam seminggu dan rata-rata lama latihan selama 90-120 menit. Serta pernah mewakili sekolah dalam lomba menari sebanyak 13 kali. Pada cluster 2 kegiatan ekstrakurikuler menari menjadi prioritas pertama dengan keinganan dari diri sendiri. Dengan rutinitas menari yaitu 2 kali dalam seminggu dan rata-rata lama latihan selama 90-120 menit. Serta pernah mewakili sekolah dalam lomba menari sebanyak 4-5 kali.

\section{DAFTAR PUSTAKA}

[1]. Winata, Y.A., Penerapan Analisis Kovarians Multivariat pada Bidang Gizi, Jurnal Matematika, 2017. 6(2), 1-10.

[2]. Alwi, W., Analisis Klaster untuk Pengelompokkan Kabupaten/Kota di Provinsi Sulawesi Selatan Berdasarkan Indikator Kesejahteraan Rakyat, Jurnal MSA, 2018. 6(1), 36-42.

[3]. Wardhani, A.K., Implementasi Algoritma K-Means untuk Pengelompokkan Penyakit Pasien pada Puskesmas Kajen Pekalongan, Jurnal Transformatika, 2016. 14(1), 30-37.

[4]. Amah, N., Wahyuningsih, S., Fidia., Analisis Cluster Non-Hirarki dengan Menggunakan Metode K-Modes pada Mahasiswa Program Studi Statistika Angkatan 2015 FMIPA Universitas Mulawarman, Jurnal Eksponensial, 2017. 8(1), 9-15.

[5]. Matondang, Z., Validitas dan Reliabilitas Suatu Instrumen Penelitian, Jurnal Tabularasa, 2009. 6(1), 87-97.

[6]. Prasetyo, E. 2014. Data Mining Mengolah Data Menjadi Informasi Menggunakan Matlab. Yogyakarta. ANDI.

[7]. Iswandiri, R., Supriyanto, W., Kecenderungan Sivitas Akademika dalm Memilih Sumber Referensi untuk Penyusunan Karya Tulis Ilmiah di Perguruan Tinggi, Jurnal Berkala Ilmu Perpustakaan dan Informasi, 2017. 13(1), 87-97.

[8]. Khumaedi, M., Reliabilitas Instrumen Penelitian Pendidikan, Jurnal Pendidikan Teknik Mesin, 2012. 12(1), 25-30.

INDAH AYUNINGTIAS

NAOMI NESSYANA DEBATARAJA : Jurusan Matematika FMIPA Untan, Pontianak,

NURFITRI IMRO’AH
: Jurusan Matematika FMIPA Untan, Pontianak, indahayuningtias07@gmail.com naominessyana@math.untan.ac.id : Jurusan Matematika FMIPA Untan, Pontianak, nurfitriimroah@math.untan.ac.id 